\title{
Function and evolution of the psbA gene family in marine Synechococcus: Synechococcus sp. WH7803 as a case study
}

\author{
Laurence Garczarek ${ }^{1,3}$, Alexis Dufresne ${ }^{1,3}$, Nicolas Blot ${ }^{1}$, Amanda M Cockshutt ${ }^{2}$, \\ Anne Peyrat ${ }^{1}$, Douglas A Campbell ${ }^{2}$, Ludovic Joubin ${ }^{1}$ and Christophe Six ${ }^{2}$ \\ ${ }^{1}$ Station Biologique, UMR 7144 CNRS et Université Pierre et Marie Curie, Roscoff cedex, France and \\ ${ }^{2}$ Photosynthetic Molecular Ecophysiology, Biology Department, Mount Allison University, Sackville, \\ New Brunswick, Canada
}

\begin{abstract}
In cyanobacteria, the D1 protein of photosystem II (PSII) is encoded by the psbA multigene family. In most freshwater strains, a D1:1 isoform of this protein is exchanged for a D1:2 isoform in response to various stresses, thereby altering PSII photochemistry. To investigate PSII responses to stress in marine Synechococcus, we acclimated cultures of the WH7803 strain to different growth irradiances and then exposed them to high light (HL) or ultraviolet (UV) radiation. Measurement of PSII quantum yield and quantitation of the D1 protein pool showed that HL-acclimated cells were more resistant to UV light than were low light- (LL) or medium light- (ML) acclimated cells. Both UV and HL induced the expression of psbA genes encoding D1:2 and the repression of the psbA gene encoding D1:1. Although three psbA genes encode identical D1:2 isoforms in Synechococcus sp. WH7803, only one was strongly stress responsive in our treatment conditions. Examination of 11 marine Synechococcus genomic sequences identified up to six psbA copies per genome, with always a single gene encoding D1:1. In phylogenetic analyses, marine Synechococcus genes encoding D1:1 clustered together, while the genes encoding D1:2 grouped by genome into subclusters. Moreover, examination of the genomic environment of psbA genes suggests that the D1:2 genes are hotspots for DNA recombination. Collectively, our observations suggest that while all psbA genes follow a concerted evolution within each genome, D1:2 coding genes are subject to intragenome homogenization most probably mediated by gene conversion.
\end{abstract}

The ISME Journal (2008) 2, 937-953; doi:10.1038/ismej.2008.46; published online 29 May 2008

Subject Category: integrated genomics and post-genomics approaches in microbial ecology

Keywords: D1; photoacclimation; photoinhibition; photosystem II; psbA; ultraviolet radiation

\section{Introduction}

Although light is essential for photosynthesis, it also provokes photoinactivation of photosystem II (PSII). The D1 polypeptide is a key protein of the core of the PSII, and is the primary target for photoinactivation (reviewed in Nishiyama et al., 2006), which must be countered by a repair cycle to replace photodamaged D1 proteins (Aro et al., 1993). When irradiance and/or ultraviolet (UV) levels increase, photoinactivation may outrun the rate of repair, leading to net photoinhibition of PSII (Aro et al.,

Correspondence: L Garczarek, Station Biologique, UMR 7144 CNRS et Université Pierre et Marie Curie, BP 74, Place Georges Tessier, 29682 Roscoff cedex, France.

E-mail: garczare@sb-roscoff.fr

${ }^{3}$ These two authors contributed equally to this work

Received 29 October 2007; revised 25 March 2008; accepted 15 April 2008; published online 29 May 2008
2005) and a decrease of photosynthetic capacity. Hence, the D1 protein shows a high rate of synthesis and degradation, so that photodamaged D1 proteins are usually rapidly replaced with newly synthesized ones (Schaefer and Golden, 1989; Bustos et al., 1990; Aro et al., 1993; Clarke et al., 1993a; Nishiyama et al., 2006). While in eukaryotes D1 is usually encoded by a single chloroplastic $p s b A$ gene, a multigene $p s b A$ family is present in most cyanobacterial genomes encoding multiple isoforms of D1 protein in many strains (Schaefer and Golden, 1989; Vrba and Curtis, 1990; Mate et al., 1998; Sicora et al., 2006).

Synechococcus sp. PCC 7942 and Thermosynechococcus elongatus BP-1 contain three psbA copies, with psbAI encoding the primary D1:1 isoform constitutively present in PSII centres (Schaefer and Golden, 1989). Excess irradiance, low temperature or other stresses leading to a 
decrease in electron transport induce expression of the $p s b A I I$ and $p s b A I I I$ genes encoding the alternate isoform D1:2, which then progressively replaces the D1:1 isoform through the ongoing action of the PSII repair cycle (Bustos et al., 1990; Clarke et al., 1993a,b, 1995; Campbell et al., 1995, 1998, 1999; Sippola et al., 1998; Kos et al., 2008). In Synechococcus sp. PCC 7942, the presence of D1:2 in PSII centres decreases the cellular susceptibility to PSII photoinactivation (Clarke et al., 1993a; Campbell et al., 1998). Amino-acid position 130, a glutamine in D1:1 and a glutamate in D1:2, is essential in the differential function of these proteins in PSII (Clarke et al., 1993a; Campbell et al., 1996; Giorgi et al., 1996b; Sane et al., 2002; Tichy et al., 2003; Kos et al., 2008). Synechocystis sp. PCC 6803 is quite different, with three $p s b A$ copies where both $p s b A I I$ and psbAIII encode a D1:1 isoform. Under stress conditions, only psbAIII expression is enhanced to provide supplemental transcripts for D1 repair (Mate et al., 1998). psbAI has a divergent sequence encoding a D1 form termed D1', which is expressed at only constitutive trace levels (Sicora et al., 2006). In Anabaena sp. PCC 7120 five $p s b A$ genes, $p s b A 0$ $I V$, are present and expressed (Sicora et al., 2006). The psbAI copy encodes a D1:1 constituting the major D1 protein under moderate excitation conditions. The psbAII-IV genes encode D1:2 isoforms and are induced upon UVB or high irradiance exposure. Similarly, to the psbAI gene of Synechocystis sp. PCC 6803 and psbA2 in Thermosynechococcus elongatus BP-1 (Kos et al., 2008), the psbAo gene of Anabaena sp. PCC 7120 is phylogenetically divergent and transcribed at only trace levels. The deeply divergent cyanobacteria Gloeobacter violaceus also contains five $p s b A$ genes, but two encode divergent D1' forms expressed at only constitutive trace levels, while the remaining three $p s b A$ genes all encode a D1:2-type isoform, with differential induction of the transcripts under excitation stress (Sicora et al., 2008).

Marine Synechococcus are ubiquitous picoplanktonic cyanobacteria, which contribute significantly to primary production, food webs, biogeochemical cycles and climate feedbacks (Waterbury et al., 1986; Olson et al., 1990; Partensky et al., 1999). These cyanobacteria constitute a well-defined phylogenetic group but exhibit a large phenotypic diversity across a large number of phylogenetic clades as defined by 16S RNA analyses (Fuller et al., 2003) and 16S-23S internal spacer sequence analyses (Ahlgren and Rocap, 2006). Although many studies have described the distribution of marine Synechococcus, the relation between their photophysiology and their phylogeny and ecology is not well understood (Six et al., 2007a). In particular, whether the functional diversity of $p s b A$ genes in marine Synechococcus is similar to that of freshwater cyanobacteria has not been investigated yet.

In this paper, we have used the recently available genomes of 11 strains of marine Synechococcus to draw the first overview of the numbers and distributions of $p s b A$ genes in this cyanobacterial group. Through genomic context analyses, phylogeny and recombination tests, we provide new insights into the evolutionary processes that maintain the unusual properties of this important gene family. In parallel, the WH7803 strain, which is so far the physiologically best-characterized marine Synechococcus strain, was used to investigate the PSII response to high light (HL) and UV stresses and to determine the function of the different $p s b A$ genes in a representative marine Synechococcus.

\section{Materials and methods}

Culture conditions and experimental procedures Synechococcus sp. WH7803 was grown at $25^{\circ} \mathrm{C}$ in $0.2 \mu \mathrm{M}$ filtered PCR-S11 medium (Rippka et al., 2000) supplemented with $5 \mathrm{mM} \mathrm{NaNO}_{3}$. Three cultures were acclimated for several weeks to continuous low light (LL, $15 \mu \mathrm{mol}$ photons $\mathrm{m}^{-2} \mathrm{~s}^{-1}$ ), medium light (ML, $75 \mu \mathrm{mol}$ photons $\mathrm{m}^{-2} \mathrm{~s}^{-1}$ ) and HL (350 $\mu \mathrm{mol}$ photons $\mathrm{m}^{-2} \mathrm{~s}^{-1}$; Sylvania Daylight 58W/ 154 fluorescent bulbs). For each growth irradiance, 91 of exponentially growing culture (about $10^{7}$ cell ml $^{-1}$ ) were split in $800 \mathrm{ml}$ aliquots in $1 \mathrm{l}$ glass or quartz Erlenmeyer flasks (Ellipse, La Chapelle la Rennes, France) and left under their initial growth irradiance for $1 \mathrm{~h}$. One of the $800 \mathrm{ml}$ glass flasks was kept in the initial conditions and used as a control. For the LL- and the ML-acclimated cultures, four glass flasks were placed under $350 \mu \mathrm{mol}$ photons $\mathrm{m}^{-2} \mathrm{~s}^{-1}$ PAR (photosynthetically active radiation, that is, HL), while four quartz flasks were kept under the initial growth irradiance supplemented with UV $\left(4.7 \mathrm{~W} \mathrm{~m}^{-2}\right.$ UVA, $0.8 \mathrm{~W} \mathrm{~m}^{-2}$ UVB) for $5 \mathrm{~h}$. Four aliquots of the HL-acclimated culture were subjected to the latter treatment, while four others were shifted to $75 \mu \mathrm{mol}$ photons $\mathrm{m}^{-2} \mathrm{~s}^{-1}$ (that is, ML). One Erlenmeyer flask for each treatment (light shift, UV shift) was withdrawn after $15 \mathrm{~min}, 1,2.5$ and $5 \mathrm{~h}$ to study the kinetics of the responses to light and UV stress. The PAR was measured in the $400-700 \mathrm{~nm}$ range using a QSL2100 quantameter (Biospherical, La Jolla, CA, USA). UVA and UVB radiations, generated from UVA-351 and UVB-313 fluorescent bulbs (Q-Panel Lab products, Cleveland, $\mathrm{OH}$, USA), were measured between $280-320$ and $320-400 \mathrm{~nm}$, respectively using a USB2000 spectroradiometer (Ocean Optics, Ew Duiven, The Netherlands).

Synechococcus sp. WH7803 growth was monitored by cytometry (Marie et al., 1999, 2000). Immediately after sampling, culture aliquots were fixed with $0.25 \%$ glutaraldehyde grade II (SigmaAldrich, St Louis, MO, USA) for $30 \mathrm{~min}$ at $4{ }^{\circ} \mathrm{C}$, flash was frozen in liquid nitrogen and stored at $-80^{\circ} \mathrm{C}$ until analysis. Cell concentration in the cultures was determined using a FacSort flow cytometer (Becton Dickinson, Franklin Lakes, NJ, USA) with laser emission set at $488 \mathrm{~nm}$. The flow rate was about $70 \mu \mathrm{lmin}^{-1}$ and the sheath fluid was distilled water. 


\section{Fluorescence measurements}

Photosystem II fluorescence was studied using a pulse amplitude-modulated fluorimeter (PhytoPAM, Walz, Effeltrich, Germany). This instrument includes modules providing excitation light at four distinct wavelengths $(470,520,645$ and $665 \mathrm{~nm})$, red actinic light peaking at $655 \mathrm{~nm}$ filtered through a short-pass filter $(<695 \mathrm{~nm})$, as well as a photomultiplier equipped with a long-pass filter set $(>710 \mathrm{~nm})$. A volume of $2 \mathrm{ml}$ culture was dark acclimated for $10 \mathrm{~min}$ in a quartz cell displaying a mirrored facet facing the photomultiplier to enhance the signal. The excitation-modulated light $(13 \mathrm{~Hz})$ was then applied to measure the basal fluorescence level $F_{0}$ with excitation at $520 \mathrm{~nm}$. The maximal fluorescence $F_{M}$ with excitation at $520 \mathrm{~nm}$ was determined in the presence of $50 \mu \mathrm{M} 3-\left(3^{\prime}\right.$, 4-dichlorphenyl)-1,1-dimethylurea under $1400 \mu \mathrm{mol}$ photons $\mathrm{m}^{-2} \mathrm{~s}^{-1}$ of red actinic light. The PSII quantum yield was calculated as:

$$
F_{\mathrm{V}} / F_{\mathrm{M}}=\left(F_{\mathrm{M}}-F_{0}\right) / F_{\mathrm{M}}
$$

\section{D1 protein quantitation by immunoblotting}

A volume of $400 \mathrm{ml}$ culture was centrifuged and the pellet was drained, flash frozen in liquid nitrogen and stored at $-80^{\circ} \mathrm{C}$ until analysis. Cell pellets were resuspended in extraction buffer (140 mM Tris base, $105 \mathrm{mM}$ Tris-HCl, $0.5 \mathrm{mM}$ ethylenediaminetetraacetic acid, 2\% lithium dodecyl sulphate, 10\% glycerol and $0.1 \mathrm{mg} \mathrm{ml}^{-1}$ PefaBloc SC (AEBSF) protease inhibitor (Roche, Basel, Switzerland) and the total protein concentration was determined using the modified Lowry DC protein assay kit (Bio-Rad, Hercules, CA, USA). The samples were then brought up to $50 \mu \mathrm{M}$ dithiotreitol, and then heated for $5 \mathrm{~min}$ at $70{ }^{\circ} \mathrm{C}$. A volume containing $2.5 \mu \mathrm{g}$ of total protein was loaded on a $4 \%-12 \%$ acrylamide precast NuPAGE Bis-Tris mini-gel (Invitrogen, Carlsbad, CA, USA) along with recombinant protein standards of D1 (Agrisera, Vännäs, Sweden) to establish a standard curve. Gels were electrophoresed for $40 \mathrm{~min}$ at $200 \mathrm{~V}$ and the proteins were transferred onto a methanol prehydrated polyvinylidene fluoride (PVDF) membrane for $80 \mathrm{~min}$ at $30 \mathrm{~V}$. Membranes were immediately immersed in Tris Buffer Saline-Tween (TBS-T) buffer pH 7.6 (0.1\% Tween 20, $350 \mathrm{~mm}$ sodium chloride, $20 \mathrm{~mm}$ Trizma base) containing 2\% (w:vol) ECL Advance blocking agent (Amersham Biosciences, Piscataway, NJ, USA) for $1 \mathrm{~h}$. Aliquots of primary antibodies against D1 or RbcL (that is, the large subunit of RuBisCO) proteins (Agrisera) were diluted at 1:50000 in TBS-T in the presence of $2 \%$ blocking agent and membranes were soaked in this solution for $1 \mathrm{~h}$ with agitation. The membranes were then extensively washed in TBS-T buffer. Antichicken secondary antibodies were applied with the same procedure as for primary antibodies. Membranes were developed by chemoluminescence using the ECL Advance reagent kit (Amersham Biosciences) with a CCD imager
(FluorSMax, Bio-Rad). Signals were quantified using the Quantity One software (Bio-Rad, Hercules, CA, USA) and the protein standard curve was generated. Protein amounts were determined by fitting the signal of the samples on the standard curve, which spanned the range of protein target abundance in the samples.

\section{RNA extraction and $c D N A$ synthesis}

Immediately after sampling, $200 \mathrm{ml}$ of culture were harvested by centrifugation at $18500 \mathrm{~g}$ for $9 \mathrm{~min}$ at $4{ }^{\circ} \mathrm{C}$ (Avanti J25 centrifuge, Beckman, Fullerton, CA, USA), followed by a second centrifugation in microtubes ( $3 \mathrm{~min}, 4^{\circ} \mathrm{C}$ at $20800 \mathrm{~g}$ in an Eppendorff 5417R centrifuge). Cell pellets were then resuspended in $300 \mu \mathrm{l}$ Trizol (Invitrogen), frozen in liquid nitrogen and stored at $-80{ }^{\circ} \mathrm{C}$ until RNA extraction. For RNA extraction, cells resuspended in Trizol were thawed by $15 \mathrm{~min}$ incubation at $65^{\circ} \mathrm{C}$ with regular vortexing. After phenol chloroform extraction, RNA was purified on Qiagen RNAeasy columns (Qiagen, Valencia, CA, USA) as recommended by the manufacturer. A DNase treatment was performed on the columns using the Qiagen RNase-free DNase Set (Qiagen). RNA was then eluted from the column in $30 \mu \mathrm{l}$ DEPC-treated water, precisely quantified using a NanoDrop spectrophotometer (ND-1000, NanoDrop Technologies, Wilmington, DE, USA) and stored at $-80^{\circ} \mathrm{C}$.

\section{Real time PCR}

Reverse transcription was carried out on $100 \mathrm{ng}$ RNA using SuperScriptII reverse transcriptase (Gibco-BRL, Gaithersburg, MD, USA) as described previously (Six et al., 2007b). Real-time PCR was performed using the GeneAmp 5700 sequence detection system and SYBR Green PCR master mix (Applied Biosystems, Foster City, CA, USA) on 1:100th diluted cDNA (but 1:1000th for $r n p B$ ) in the presence of $200 \mathrm{nM}$ primers. The PCR reaction programme consisted of a sequence of $10 \mathrm{~min}$ at $95^{\circ} \mathrm{C}$ followed by 40 cycles of $15 \mathrm{~s}$ at $95^{\circ} \mathrm{C}$ and $1 \mathrm{~min}$ at $60{ }^{\circ} \mathrm{C}$. Occurrence of a single amplicon was systematically checked by performing a melting curve.

Gene-specific primers for both reverse transcription and real-time PCR were designed using PrimerExpress software (V2.0) from Applied Biosystems (Table 1). To amplify specifically each of the four psbA copies present in Synechococcus sp. WH7803, primers were selected in the $5^{\prime}$-UTR of the genes. Primer specificity was checked on plasmid DNA (PCR2.1; Invitrogen) containing the upstream sequences of the four $p s b A$ copies. Furthermore, these plasmids, after linearization, were used to perform a standard curve for absolute quantification of each $p s b A$ transcript in LL-, ML- and HL-acclimated cultures.

The relative expression of each $p s b A$ gene in response to $\mathrm{HL}$ and $\mathrm{UV}$ stresses were calculated 
Table 1 Primers used for real-time PCR reactions for Synechococcus sp. WH7803. All primers are specific for the targeted gene except primers designed to amplify the four $p s b A$ copies present in Synechococcus sp. WH7803

\begin{tabular}{|c|c|c|}
\hline Open reading frame $(O R F)$ & Forward primer $\left(5^{\prime} \rightarrow 3^{\prime}\right)$ & Reverse primer $\left(5^{\prime} \rightarrow 3^{\prime}\right)$ \\
\hline SynWH7803_0366 & CCATGGCTGGACGCTAACA & GTCGTTGTGAAGAAGCGTTGAG \\
\hline SynWH7803_0784 & AATCCAGGCTTTCTCTGAACGT & GCGAATTGCGGTAGCCATAA \\
\hline SynWH7803_0790 & TTTCTTTACCGCTGAAGGGTTT & GCTGAATGGTGGTGGTCATG \\
\hline SynWH7803_2084 & TCTTTAGCGGCCGTCGAT & CGGAAGTTATCCAGAGCTTTATGAA \\
\hline All ORFs & TGGCTGCCCACGGTTACT & TGCGGCTGTTGTTGAAGGA \\
\hline
\end{tabular}

using the $2^{-\Delta \Delta C_{\mathrm{T}}}$ method as described in the Applied Biosystems user bulletin no. (http://dna-9.int-ed. uiowa.edu/RealtimePCRdocs/Compar_Anal_Bulletin2. pdf) with the sample taken just before the shift to stress conditions $\left(\mathrm{T}_{0}\right)$ as a reference and $\operatorname{rnp} B$ as an internal standard to normalize the relative transcript levels (Mary and Vaulot, 2003). These induction values, together with the absolute quantification of each $p s b A$ transcript at $\mathrm{T}_{0}$, allowed measuring the proportion of each transcript within the $p s b A$ pool throughout the light treatements. To ensure a similar amplification efficiency of the reference and target genes (difference $<5 \%$ ) on both plasmids and cDNA template, standard curves were generated for each set of primers.

\section{Phylogenetic and genomic analyses}

Annotation files were downloaded from the Genome section of the NCBI databases for the following Synechococcus and Prochlorococcus genomes:Synechococcus spp. WH7803 (NC_009481), RCC307 (NC_009482), WH8102 (NC_005070), CC9902 (NC_007513), CC9605 (NC_007516), CC9311 (NC 008319), RS9916 (NZ AAUA00000000), RS9917 (NZ_AANP00000000), BL107 (NZ_AATZ00000000), WH7805 (NZ_AAOK00000000) and WH5701 (NZ_AANO00000000) and Prochlorococcus spp. MED4 (NC_005072), SS120 (NC_005042), MIT9313 (NC_005071) and NATL2A (NC_007335). Nucleotide and protein sequences of the $p s b A$ genes were extracted from these files for Synechococcus and Prochlorococcus and retrieved from the CYORF database (http://cyano.genome.jp/) for the freshwater cyanobacteria. Because of the extreme conservation of the $p s b A$ genes at the protein level, nucleotide sequences were aligned using protal2DNA (http:// bioweb.pasteur.fr/seqanal/interfaces/protal2dna.html) according to a protein alignment generated using the CLUSTALW (Thompson et al., 1994) as implemented in the BIOEDIT freeware (Hall, 1999). To avoid biases due to large GC\% variability, phylogenetic analyses were performed using the first and second codon position. Maximum likelihood tree was inferred using PHYML V2.4.4 (Guindon and Gascuel, 2003) with the K2P substitution model and the estimation of the gamma distribution parameter of the substitution rates among sites and of the proportion of invariables sites. Bootstrap analyses including 1000 replicate data sets were used to estimate the relative confidence of internal nodes using both neighbor-joining and maximum parsimony methods. Phylogenetic trees were edited using the program MEGA3 V3.1 (Kumar et al., 2004). To complement these phylogenetic analyses and highlight potential recombination events, an evolutionary network was developed with SplitsTree v4.2 (Huson and Bryant, 2006) using an alignment of the nucleotide sequences of all marine Synechococcus psbA genes including the variable third codon position. Computing of the network was made using the K2P model for the distances and the NeighborNet method for distance transformation. The Phi test was used to detect the occurrence of recombination events between $p s b A$ sequences (Bruen et al., 2006). Moreover, the Genetic Algorithm Recombination Detection (GARD) (Kosakovsky Pond et al., 2006) was used to identify recombination breakpoints in the alignments of $p s b A$ genes coding either D1:1 only, D1:2 only or both isoforms. Analysis was performed using the HKY85 model for the substitution bias, the beta-gamma model with three rate classes for the site-to-site variation of substitution rates and the GARD option for the detection method.

To examine the conservation of the gene order around the $p s b A$ genes, orthologous relationships among $p s b A$ flanking genes were investigated. Families of orthologous genes were delineated using the TribeMCL algorithm after Basic Local Alignment Search Tool (BLAST) all-against-all comparisons of every D1 protein sequence from the 11 Synechococcus genomes (Altschul et al., 1997; Enright et al., 2002). An e-value cut-off of $10^{-12}$ was chosen as threshold for the BLAST comparisons. Nonmodelled genes, which were missed by the open reading frame (ORF) finding softwares during genome annotations were manually added to the data set.

\section{Results}

Growth of Synechococcus sp. WH7803

Cultures of Synechococcus sp. WH7803 acclimated to 15 (LL), 75 (ML) and $350 \mu \mathrm{mol}$ photons $\mathrm{m}^{-2} \mathrm{~s}^{-1}$ (HL) exhibited different growth rates of $0.46 \pm 0.06$, $1.04 \pm 0.14$ and $1.15 \pm 0.19 \mathrm{~d}^{-1}$, respectively. These values are typical for marine Synechococcus (Kana and Glibert, 1987; Moore et al., 1995; Six et al., 2004). UV inhibited cell growth in the three culture 
conditions (Figure 1). We did not observe significant growth recovery within $24 \mathrm{~h}$ after UV exposure in any culture condition. When transferred from LL or ML to HL conditions, only a slight decrease of growth rate was observed relative to control cultures and both light-acclimated cultures (LL and ML) had recovered about $80 \%$ of their growth rate after $24 \mathrm{~h}$ (Figures 1a and b). HL cultures shifted to ML responded by a slight growth decrease (Figure 1c). Although some variability in the results was observed, the HL cultures were capable of almost regaining their initial growth rate when shifted back under HL (not shown).
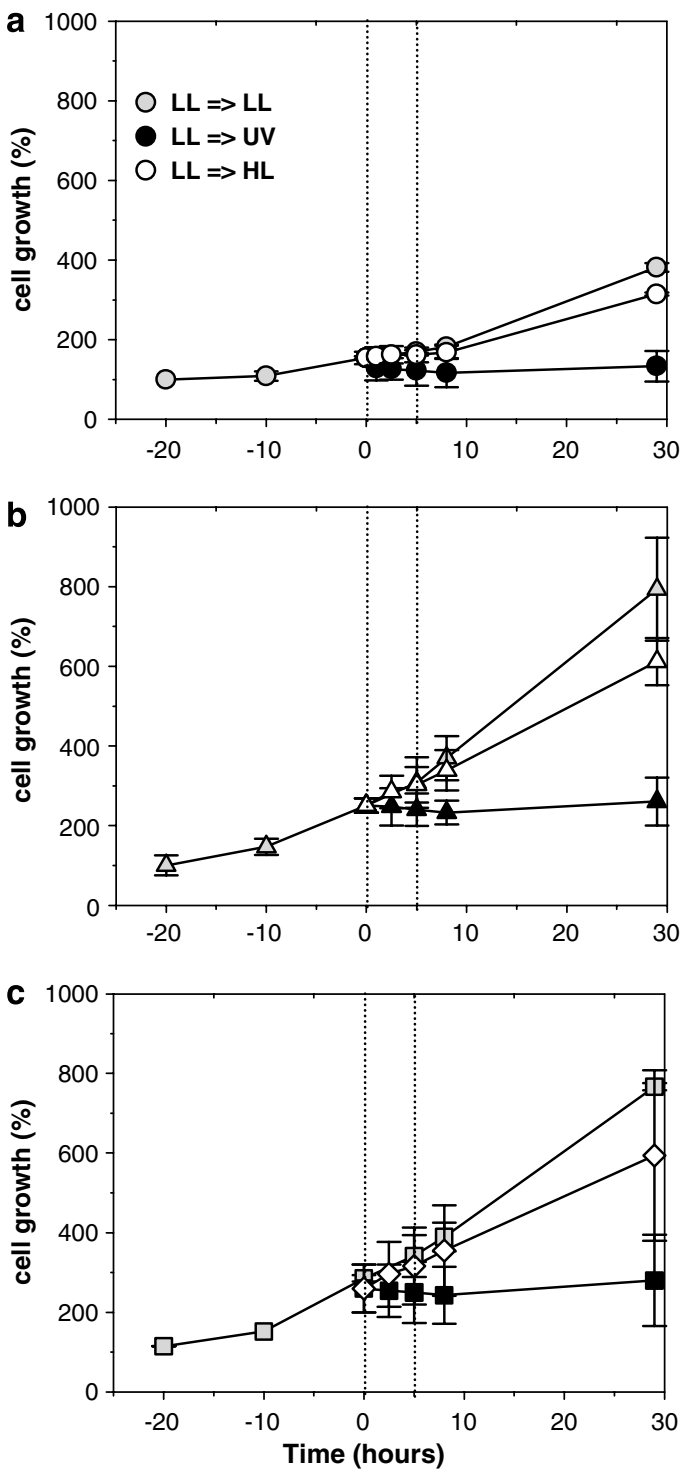

Figure 1 Growth curves of Synechococcus sp. WH7803 acclimated to (a) LL, (b) ML and (c) HL and transiently submitted to UV (black symbols), HL (white symbols except diamonds) or ML (white diamonds) for $5 \mathrm{~h}$ followed by return to the original growth conditions. The cell concentration is expressed as percentage of the initial condition. Control cultures are indicated by grey symbols and the treatment period is delineated by dotted lines. These data are based on three independent experiments. HL, high light; LL, low light; ML, medium light; UV, ultraviolet.
PSII photoinactivation in Synechococcus sp. WH7803 We used pulse amplitude-modulated fluorimetry to assess PSII activity through the different light treatments applied to LL, ML and HL cultures of Synechococcus sp. WH7803 (Figure 2). UV treatments induced a strong PSII photoinhibition for cells acclimated to all three PAR conditions, shown by a drastic drop of $\mathrm{F}_{\mathrm{V}} / \mathrm{F}_{\mathrm{M}}$ at $5 \mathrm{~h}$. The cells were capable of a slow but significant recovery of the function of their PSII after $24 \mathrm{~h}$, demonstrating that the applied UV dose was not lethal. It should be noted that the control cultures showed some decrease in $\mathrm{F}_{\mathrm{V}} / \mathrm{F}_{\mathrm{M}}$ due to culture aging, especially, in the fast growing HL cultures.

The rate of UV photoinhibition was interestingly quite different depending on the cell light history, with LL cultures suffering net photoinhibition under UV about twice as fast as the HL culture ones (Figure 2d). LL and ML cells exhibited different patterns of PSII quantum-yield variation upon HL exposure (Figures 2a and b). In the LL cultures, this parameter dropped from 0.6 at the beginning of the experiment to 0.3 after $5 \mathrm{~h}$ of HL, while ML cultures stabilized at 0.4 after $1 \mathrm{~h}$ HL exposure, which corresponds to the initial value of HL cultures. When shifted back to initial light conditions, the ML-acclimated cells recovered faster than LL-acclimated cells and reached their initial PSII quantumyield value within $8 \mathrm{~h}$. When the HL cultures were transferred under $\mathrm{ML}, \mathrm{F}_{\mathrm{V}} / \mathrm{F}_{\mathrm{M}}$ monitoring indicated a rapid increase in PSII quantum yield, which almost reached the initial value of ML cultures (Figure 2c). When shifted back to HL, this HL culture returned to its initial $F_{V} / F_{M}$ value within $1 \mathrm{~h}$.

D1 protein content in Synechococcus sp. WH7803 Cultures from all the growth light conditions responded to UV with a drop in D1 content (Figure 3a). However, the LL cultures showed a more rapid and pronounced decrease compared to ML and HL cultures. In response to HL stress, the D1 content of LL-acclimated cultures rapidly and strongly increased with a transient doubling after $2.5 \mathrm{~h}$ exposure (Figure $3 \mathrm{~b}$ ), followed by a decline back towards the initial D1 levels. In contrast, D1 cell contents of ML cultures were not affected by an increase of irradiance. Likewise, no variation in the size of the cellular D1 protein pool was observed on the immunoblots of the HL cultures upon ML exposure.

Expression of psbA genes in Synechococcus $s p$. WH7803

The total pool of psbA transcripts, monitored using primers common to all four psbA genes in Synechococcus sp. WH7803, showed significant changes upon UV and HL exposure (Figure 4). In cultures from all the LL and ML light-acclimation states, UV provoked a sharp 8-12-fold increase in the $p s b A$ 

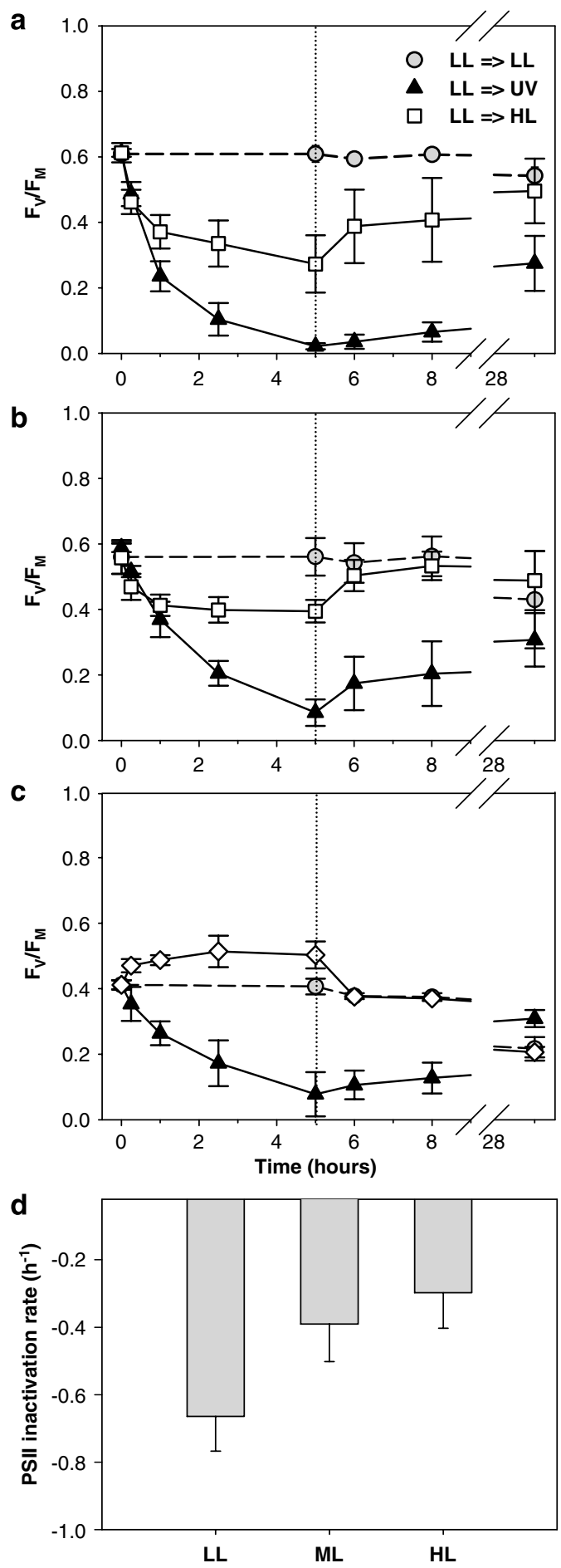

Figure 2 Variations of PSII maximal photochemical yield $\left(\mathrm{F}_{\mathrm{V}} / \mathrm{F}_{\mathrm{M}}\right)$ in Synechococcus sp. WH7803 acclimated to (a) LL, (b) ML and (c) HL and submitted to UV (filled triangles), HL (open squares) or ML (open diamonds) for $5 \mathrm{~h}$. Control cultures are indicated by grey circles and dashed lines. The end of the stress and beginning of the recovery period is indicated by the dotted line. (d) PSII photoinhibition rates in response to UV treatment. These data are based on at least three independent experiments. HL, high light; LL, low light; ML, medium light; UV, ultraviolet; PSII, photosystem II.

transcript pool within $1 \mathrm{~h}$, which then partly fell back towards control levels. In HL-acclimated cultures, however, UV exposure provoked only a small induction of $p s b A$ transcripts above the initial levels. In the LL-acclimated culture, HL treatment led to an increase of the global $p s b A$ transcript pool.

Using gene-specific primers, it is revealed that SynWH7803_0784 and SynWH7803_0790 transcripts constituted most of the psbA mRNA pool. While SynWH7803_0784, encoding D1:1, was the dominant form in LL-acclimated cells (90\%), the proportion of SynWH7803_0790, encoding D1:2, strongly increased in cultures acclimated to higher light intensities (ML and HL) reaching up to $85 \%$ of total psbA mRNA in HL-acclimated cells. Thus, it seems that the PSII of LL cultures contained mostly D1:1 proteins, whereas the PSII of HL cells contained more D1:2 proteins as a result of photoacclimation.

Furthermore, the proportion of different $p s b A$ transcripts was rapidly altered by HL or UV exposure (Figure 4). Although in our experimental conditions, this alteration was faster in response to UV than to HL stress and in LL-compared to HL-acclimated cells, the SynWH7803_0790 transcript, encoding D1:2, made up at least $80 \%$ of the total psbA mRNA pool after $1 \mathrm{~h}$ of stress in all stress conditions. Measurement of the fold change of each transcript relative to $\mathrm{T}_{0}$ showed that these modifications of $p s b A$ mRNA distribution are due to both repression of SynWH7803_0784 expression and activation of SynWH7803 0790 expression. A slight induction of the two other $p s b A$ gene copies encoding D1:2, SynWH7803_0366 and SynWH7803_2084, also occurred although both transcripts constituted only a small proportion of the $p s b A$ mRNA pool even under stress conditions. In contrast, the psbA genes were inversely regulated in HL cultures shifted to ML, leading to the rapid accumulation of the SynWH7803_0784 mRNA encoding D1:1 to $56 \%$ after $15 \mathrm{~min}$. Altogether, these data show that by exerting a strong influence on the relative contribution of $p s b A$ transcripts in the initial pool, light history of the cells is the key to responses to high light and UV stresses.

psbA gene diversity in marine cyanobacteria

Table 2 summarizes the number and the isoform type of $p s b A$ genes present in all marine Synechococcus sequenced to date as well as in six freshwater cyanobacteria and four Prochlorococcus spp. strains shown for comparison. As a working definition, we define D1:1 and D1:2 protein isoforms on the basis of the occurrence of amino acid Gln130 in D1:1 and Glu130 in D1:2 (Giorgi et al., 1996a). While Prochlorococcus spp. possess 1-3 psbA copies encoding only the D1:1 isoform, all other studied cyanobacteria except Synechocystis sp. PCC 6803 (Mate et al., 1998) and Gloeobacter (Sicora et al., 2008) possess both D1 isoforms. Three (CC9605) to 
a

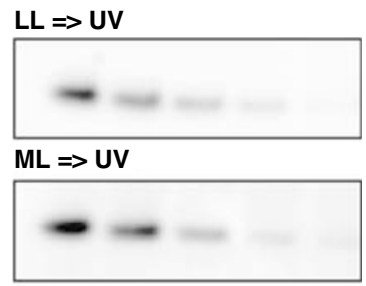

HL $=>$ UV

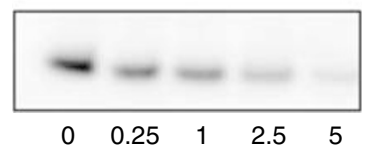

b
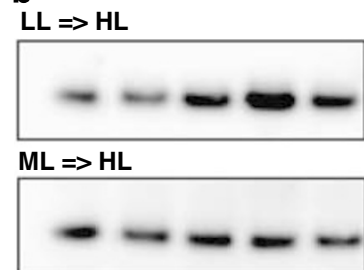

$H L \Rightarrow M L$

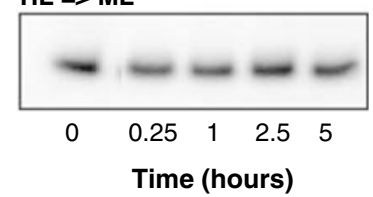

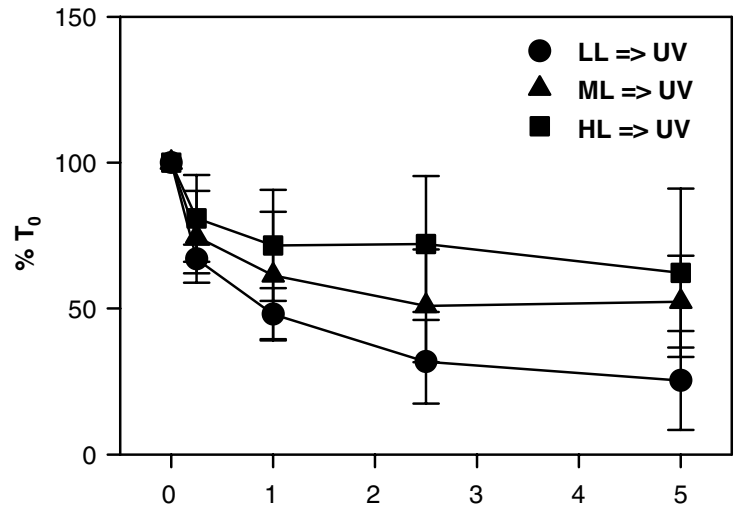

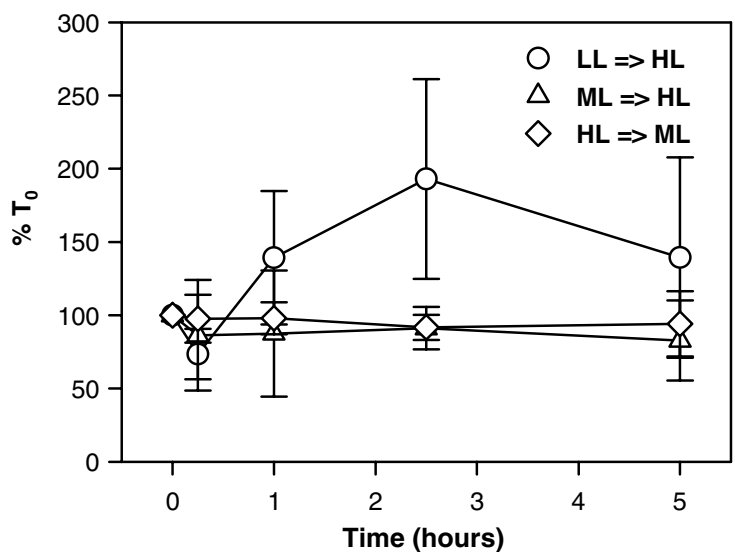

Figure 3 Variations of PsbA protein pool determined by immunoblotting with polyclonal antibody on Synechococcus sp. WH7803 grown under LL (circles), ML (triangles) or HL (squares or diamonds) and submitted to (a) UV (filled symbols), (b) HL or ML (open symbols). The plots present quantifications of biological triplicates of the representative blots on the left. These data are based on four independent experiments. HL, high light; LL, low light; ML, medium light; UV, ultraviolet.

six (WH7805) psbA genes have been identified per Synechococcus genome, with most of the strains possessing four psbA gene copies (Table 2). In each strain, only one $p s b A$ gene encodes the D1:1 isoform, which shares a high percentage of nucleotide identity (90-94\%) with the D1:2 coding genes as in freshwater cyanobacteria. Furthermore, in both marine and freshwater cyanobacteria, D1:2 isoform encoding genes show an extremely low level of divergence within genomes. Indeed, these D1:2 isoform genes are nearly identical within each marine Synechococcus strain at both the protein (99.94\%-100\% identity; Supplementary Table 1) and nucleotide level (99.86\%-100\% identity; Supplementary Table 2). These D1:2 protein sequences are even identical between the two clade IV Synechococcus strains, BL107 and CC9902, and the same applies to Synechococcus spp. WH7803 and WH7805. This clearly shows that the D1:2 isoform encoding genes have undergone concerted evolution in all cyanobacterial genomes examined in this study. Synechococcus sp. RS9917 possesses one $p s b A$ sequence very distant from all marine Synechococcus $p s b A$ genes. Such a divergent $p s b A$ gene copy has also been identified in Synechocystis sp. PCC 6803 (Mate et al., 1998; Sicora et al., 2006), Anabaena sp. PCC 7120 (Sicora et al., 2006) and Gloeobacter violaceus (Sicora et al., 2008). Lastly, two fragments encoding partial C-terminal regions of the D1 protein were found in WH7803 (SynWH7803_2082; 42 amino acids) and in RS9916 (RS9916_39526; 112 amino acids).

Genomic environment of psbA genes in marine Synechococcus

The investigation of the genomic context of each psbA copy in all marine Synechococcus strains revealed that most $p s b A$ genes are located into three main genomic regions (Figure 5). The two first regions contain only D1:2-encoding genes, while the third one carries the D1:1-encoding gene as well as 0-2 genes encoding the D1:2 isoform. Four Synechococcus genomes possess an additional $p s b A$ gene (SYNW0983, RS9917_12975, WH5701_10719 and RCC307_2009), which is present in none of the three main genomic regions. Notably, groups of orthologues located upstream from the $p s b A$ gene in the three main regions have a conserved gene order, which has been modified mainly by strain-specific gene deletion or insertion of unique genes. In contrast, orthologues found downstream of $p s b A$ genes are characterized by a large number of translocations as shown by the occurrence of 

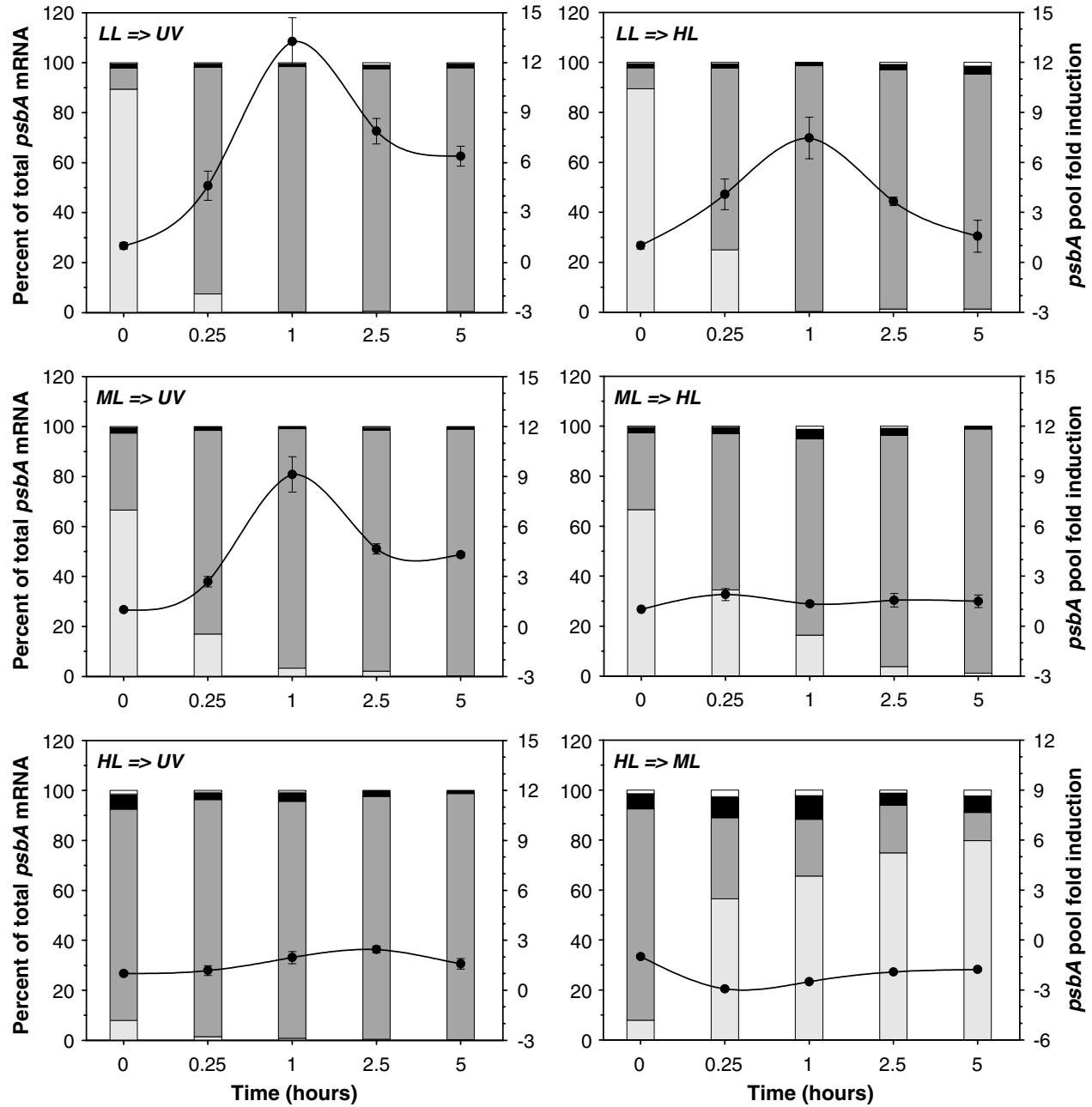

Figure 4 Relative contributions of the four psbA transcripts present in Synechococcus sp. WH7803 throughout light treatments after normalizing each transcript to the sum of the transcript pool, expressed as 100\% (left scale): SynWH7803_0784 (encoding D1:1 isoform, light grey), SynWH7803_0790 (encoding D1:2 isoform, dark grey), SynWH7803_0366 (encoding D1:2 isoform, black) and SynWH7803_2084 (encoding D1:2 isoform, white). The relative size of the total psbA transcript pool normalized to the expression level of the $\operatorname{rnp} B$ gene was plotted as black circles (right scale). The cultures were grown under LL, ML or HL and submitted to UV (left panel), HL or ML (right panel). Each real-time PCR was performed in triplicate. HL, high light; LL, low light; ML, medium light; UV, ultraviolet.

strain-specific associations of the same genes in a different order. These observations strongly suggest that $p s b A$ genes constitute hotspots for intragenomic homologous recombination.

\section{Phylogeny and evolution of psbA genes}

Phylogenetic analyses performed using the first and second codon position showed that all psbA gene sequences of marine cyanobacteria, except the divergent $p s b A$ sequence of the halotolerant Synechococcus sp. RS9917, form a monophyletic group within cyanobacteria (Figure 6). psbA genes of marine Synechococcus are dispersed within two main clusters of sequences corresponding to the two D1 isoforms (Figure 6). The first cluster gathers the D1:1-encoding genes of each of the marine Synechococcus genomes. The second cluster contains the D1:2-encoding genes. Within the D1:2 cluster, the genes always group together according to the genome to which they belong. A much larger genetic diversity exists among the freshwater cyanobacteria sequences used in this study, leading to a more complex pattern of clustering of the $p s b A$ genes in the phylogenetic tree (Figure 6). As in marine Synechococcus, D1:2 psbA genes tend to group according to the genome to which they belong. However, contrary to what is observed in marine cyanobacteria, D1:2 genes also cluster with D1:1 genes from the same genome. Thermosynechococcus elongatus appears to be an exception, since one $\mathrm{D} 1: 2 \mathrm{psbA}$ gene seems to be closer to the $\mathrm{D} 1: 1$ gene than to the second D1:2 copy. The divergent psbA genes either group with their D1:2 counterparts as in Gloeobacter violaceus or form a separate cluster as in the Anabaena strains and in Synechocystis sp. PCC 6803. Interestingly, the genetic distances among the organisms seem to affect the clustering of 
Table $2 p s b A$ gene copies in some freshwater and marine cyanobacteria. Note that D1:1 and D1:2 isoforms were distinguished based on the amino-acid 130 residue

\begin{tabular}{|c|c|c|c|c|c|}
\hline Cyanobacteria strains & Divergent psbA & $\begin{array}{l}\text { D1:1 isoform } \\
\text { coding gene }\end{array}$ & D1:2 isoform coding gene & $\begin{array}{l}\text { Light } \\
\text { response }^{\mathrm{a}}\end{array}$ & References \\
\hline Synechococcus sp. PCC 7942 & & Synpcc7942_0424 & $\begin{array}{l}\text { Synрсc7942_1389, } \\
\text { Synрсc7942_0893 }\end{array}$ & HL, UV, & $\begin{array}{l}\text { (Bustos et al., 1990; Clarke et al., } \\
\text { 1993b; Campbell et al., 1998) }\end{array}$ \\
\hline $\begin{array}{l}\text { Thermosynechococcus elongatus BP-1 } \\
\text { Synechococcus sp. PCC } 6301\end{array}$ & & $\begin{array}{l}\operatorname{tr} 1843 \\
\text { svc1093 }\end{array}$ & $\operatorname{tr} 1477, \operatorname{tr} 1844$ & HL & (Sander et al., 2007) \\
\hline Synechocystis sp. PCC 6803 & slr1181 & slr1311, sll1867 & & HL,UV & $\begin{array}{l}\text { (Mate et al., 1998; Vass et al., } \\
\text { 2000; Tichy et al., 2003; } \\
\text { Allakhverdiev and Murata, } \\
\text { 2004) }\end{array}$ \\
\hline Anabaena sp. PCC 7120 & alr3742 & alr4866 & all3572, alr3727, alr4592 & HL, UV & (Sicora et al., 2006) \\
\hline $\begin{array}{l}\text { Anabaena variabilis } \\
\text { Gloeobacter violaceus sp. PCC } 7421\end{array}$ & $\begin{array}{l}\text { Ava4121, Ava1583 } \\
\text { glr1706, glr2656 }\end{array}$ & Ava2138 & $\begin{array}{l}\text { Ava2460, Ava1597, Ava3553 } \\
\text { glr2322 glro779, gll3144 }\end{array}$ & & (Sicora et al., 2008) \\
\hline $\begin{array}{l}\text { Prochlorococcus sp. MED4 (HL clade) } \\
\text { Prochlorococcus sp. SS120 (LL clade) } \\
\text { Prochlorococcus sp. MIT9313 (LL clade) } \\
\text { Prochlorococcus sp. Natl2a (LL clade) }\end{array}$ & & $\begin{array}{l}\text { PMM0223 } \\
\text { Pro0252 } \\
\text { PMT0419, PMT1532 } \\
\text { NT06PM0673, } \\
\text { NT06PM0907, } \\
\text { NT06PM1877 }\end{array}$ & & $\begin{array}{l}\text { HL } \\
\text { HL }\end{array}$ & $\begin{array}{l}\text { (Garcia-Fernandez et al., 1998) } \\
\text { (Garcia-Fernandez et al., 1998) }\end{array}$ \\
\hline Synechococcus sp. CC9311 (clade I) & & sync_1858 & $\begin{array}{l}\text { sync_1856, sync_0368, } \\
\text { sync_2384 }\end{array}$ & & \\
\hline Synechococcus sp. CC9605 (clade II) & & Syncc9605_1042 & $\begin{array}{l}\text { Syncc9605_0307, } \\
\text { Syncc9605_0519 }\end{array}$ & & \\
\hline Synechococcus sp. WH8102 (clade III) & & SynW1470 & $\begin{array}{l}\text { SynW0983, SynW1919, } \\
\text { SynW2151 }\end{array}$ & & \\
\hline Synechococcus sp. BL107 (clade IV) & & BL107_14260 & $\begin{array}{l}\text { BL107_08169, BL107_08179, } \\
\text { BL107_09336, BL107_09351 }\end{array}$ & & \\
\hline Synechococcus sp. CC9902 (clade IV) & & Syncc9902_0943 & $\begin{array}{l}\text { Syncс } 9902 \_1814, \\
\text { Syncс9902_1817, } \\
\text { Syncс9902_2036 }\end{array}$ & & \\
\hline Synechococcus sp. WH7803 (clade V) & & SynWH7803_0784 & $\begin{array}{l}\text { SynWH7803_0790, } \\
\text { SynWH7803_0366, } \\
\text { SynWH7803_2084 }\end{array}$ & HL, UV & This study \\
\hline Synechococcus sp. WH7805 (clade VI) & & WH7805_00300 & $\begin{array}{l}\text { WH7805_00315, } \\
\text { WH7805_00325, } \\
\text { WH7805_07341, } \\
\text { WH7805_12128,WH7805 } 12138\end{array}$ & & \\
\hline Synechococcus sp. RS9917 (clade VIII) & RS9917_12975 & RS9917_10626 & RS9917_03498, RS9917_08025 & & \\
\hline Synechococcus sp. RS9916 (clade IX) & & RS9916_27899 & $\begin{array}{l}\text { RS9916_34917, } \\
\text { RS9916_39506,RS9916_39561 }\end{array}$ & & \\
\hline Synechococcus sp. RCC307 (clade X) & & SynRCC307 1441 & $\begin{array}{l}\text { SynRCC307_1440, } \\
\text { SynRCC307_2009, } \\
\text { SynRCC307_2183 }\end{array}$ & & \\
\hline $\begin{array}{l}\text { Synechococcus sp. WH5701 } \\
\text { (subcluster 5.2) }\end{array}$ & & WH5701_12653 & $\begin{array}{l}\text { WH5701_01120, } \\
\text { WH5701_10719, WH5701_15526 }\end{array}$ & & \\
\hline
\end{tabular}

${ }^{a}$ Change in $p s b A$ expression in response to high light or ultraviolet stress measured in previous studies. 


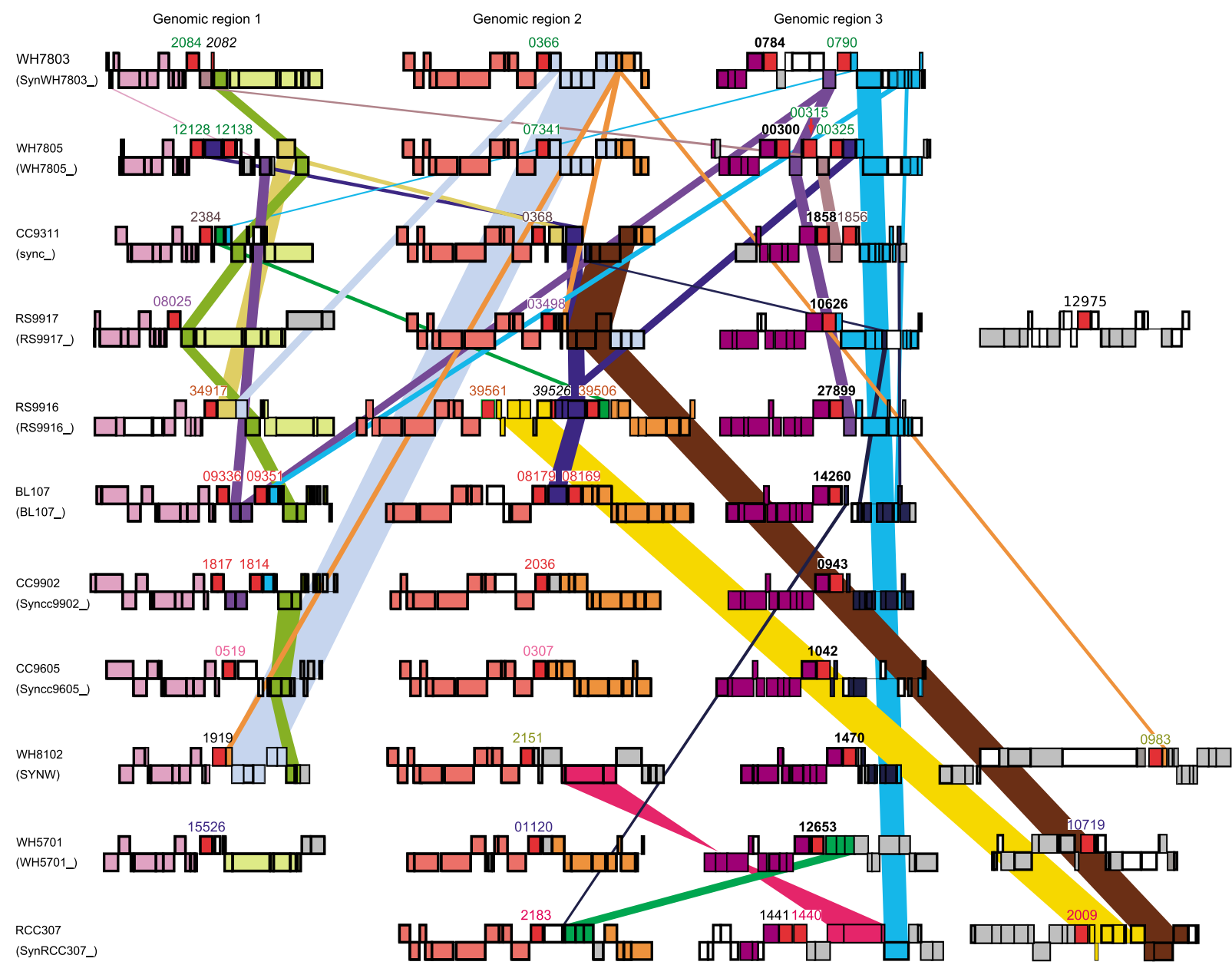

Figure 5 Genomic rearrangements in the vicinity of $p s b A$ genes. Marine Synechococcus psbA genes (in red) surrounded by 10 upstream and downstream genes are shown according to the strain (horizontally) and to the genomic area they belong to (vertically). The first three columns represent the three main genomic regions (GR) surrounding the $p s b A$ genes. The fourth column groups the psbA genes whose upstream regions are not conserved in the other genomes. psbA genes are labelled with the numerical part of their gene names, while prefixes of gene names are mentioned in brackets on the left. The same colour has been given to the open reading frame number of identical D1:2-coding genes. Genes coding for the D1:1 isoform (GR 3) are labelled in bold, while fragments of psbA genes are labelled in italic. Identical colours have been used for orthologues forming colinear units in the different genomes. Grey genes have orthologues in at least one other Synechococcus genome but which are not located near a $p s b A$ gene. Strain-specific genes are shown in white. Genomic rearrangements upstream and downstream of $p s b A$ genes are indicated by coloured bars linking single orthologues or groups of orthologues. When several strains show the same recombination event as Synechococcus sp. WH7803, rearrangements are indicated only in this strain. When Synechococcus sp. WH7803 is not concerned by a recombination event, the next strain affected by this event with the highest position in the figure will be used as reference.

the $p s b A$ genes. Indeed, $p s b A$ genes from closely related cyanobacteria group together as well as according to the isoform they are coding for, such as for Synechococcus PCC 6301 and PCC 7942, and in the two Anabaena strains. Altogether, this suggests that the concerted intragenomic evolution observed between D1:2 copies also occurred among the D1:2 and the D1:1 genes over longer time scales.

A similar situation is found in marine Synechococcus when all three codon positions are taken into account. Indeed, phylogenetic trees (not shown) as well as evolutionary network (Supplementary Figure 1) showed that D1:1 and D1:2 isoforms encoding genes cluster together in several strains such as CC9902, BL107, CC9311 and WH5701. This strongly suggests the occurrence of intragenomic recombination events between both isoform-coding genes. Statistical tests (Phi test) indeed allowed to detect a significant recombination signal in the alignment of all psbA genes of marine Synechococcus (Table 3). Furthermore, recombination analyses using the GARD genetic algorithm allowed identification of three recombination breakpoints, dividing the $p s b A$ genes alignment into four segments, each of them leading to phylogenetic trees with discordant topologies (Figure 7, Table 3). Only the tree inferred from the first 151 nucleotides showed a clear separation of the D1:1- and D1:2-encoding genes as in the tree based on the first two codon positions (Figure 6). In contrast, all three phylogenetic trees based on the other segments, 


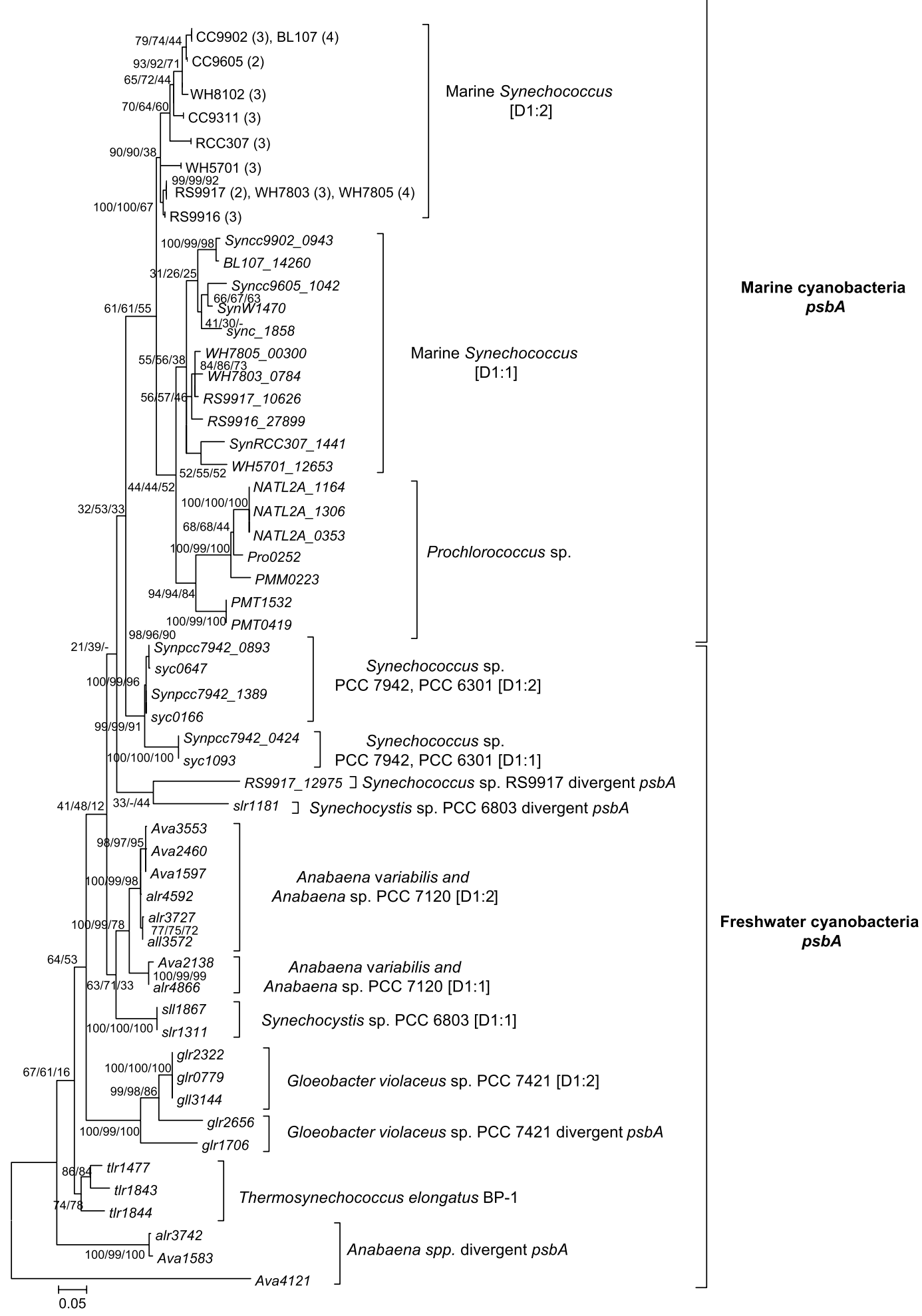

Figure 6 Maximum likelihood tree of $p s b A$ gene sequences from freshwater and marine cyanobacteria Numbers at the nodes correspond to bootstrap values for 1000 replicate trees obtained with the maximum likelihood, neighbor-joining and maximum parsimony methods (ML/NJ/MP). Only bootstrap values higher than 65 are shown. Details on sequences used in this analysis are listed in Table 2. For readability, marine Synechococcus clusters containing several closely related D1:2-encoding genes have been compressed. The number of gene copies within each Synechococcus genome is indicated in brackets and the encoded isoform under square brackets.

although different, showed the clustering of D1:1- and D1:2-coding genes from the same genome, indicating intragenomic recombination events affecting these $p s b A$ fragments. Likewise, recombination breakpoints have been identified in the alignment gathering either the D1:1- or the 
Table 3 Statistical (Phi test) and recombination Genetic Algorithm Recombination Detection (GARD) tests performed on three Synechococcus psbA alignments

\begin{tabular}{|c|c|c|c|}
\hline Alignment & $\begin{array}{l}\text { Number of unique } \\
\text { sequences }\end{array}$ & Phi test P-value & $\begin{array}{l}\text { Number and positions of } \\
\text { recombination breakpoints }\end{array}$ \\
\hline All psbA genes & 35 & $1.83 \times 10^{-22}$ & $3(151,522,858)$ \\
\hline D1:1-coding genes & 11 & $6.58 \times 10^{-08}$ & $6(186,291,480,642,774,971)$ \\
\hline D1:2-coding genes & 23 & $5.70 \times 10^{-03}$ & $1(660)$ \\
\hline
\end{tabular}

$100 \%$ identical nucleotide sequences have been excluded from the alignments.

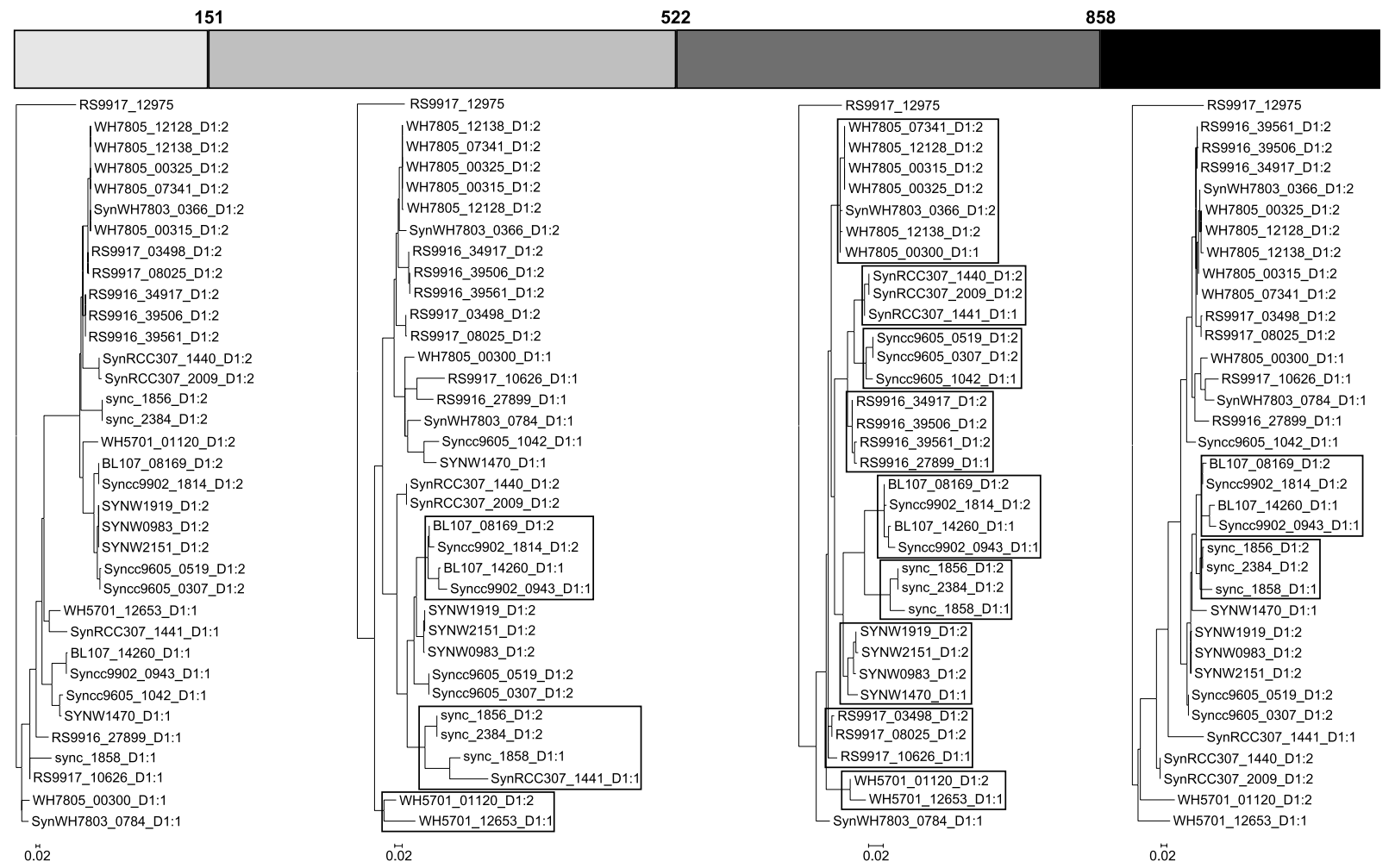

Figure 7 Recombination analysis of marine Synechococcus psbA genes using the Genetic Algorithm Recombination Detection (GARD). The identified $p s b A$ segments are represented as contiguous shaded boxes with the breakpoint positions indicated above. Phylogenetic trees corresponding to each segment of D1:1 and D1:2 coding genes are shown, rooted with the RS9917 divergent psbA gene (RS9917_12975). Clusters suggesting putative recombination events between the two isoforms of psbA genes are framed in black (see online version for colour figure).

D1:2-coding genes, providing segments (Table 3) with distinct phylogenetic trees (not shown). The Phi test also confirmed that the recombination events occurred within each D1 isoform-coding genes (Table 3). Taken together, all these analyses show that recombinations have affected the evolution of $p s b A$ genes coding for both isoforms.

\section{Discussion}

The photophysiology of cyanobacterial PSII has been primarily studied in freshwater model organisms such as Synechocystis sp. PCC 6803, Synechococcus sp. PCC 7942 and Anabaena sp. PCC 7120. To understand the stress response of PSII in marine Synechococcus, and more specifically the function of the $p s b A$ gene family, we submitted the
WH7803 strain acclimated to different growth irradiances to UV and PAR stresses.

Ultraviolet treatments induced a strong decrease in PSII quantum yield whatever be the initial growth irradiance (Figures 1 and 2). Cells acclimated to HL, however, appeared to be better prepared to withstand subsequent UV stress, since the photoinhibition rate was lower for the HL cultures than for the other cultures (Figure 2d). The smaller decrease of D1 content in HL cultures than in ML and LL cultures suggests that the D1 turnover is faster in HL cells than in the other cultures (Figure 3). The influence of light history of cultures was also quite visible at the transcriptomic level, as the relative contribution of the different psbA transcripts differed significantly depending on growth irradiance (Figure 4). Similarly, to most freshwater cyanobacteria, we show that in Synechococcus 


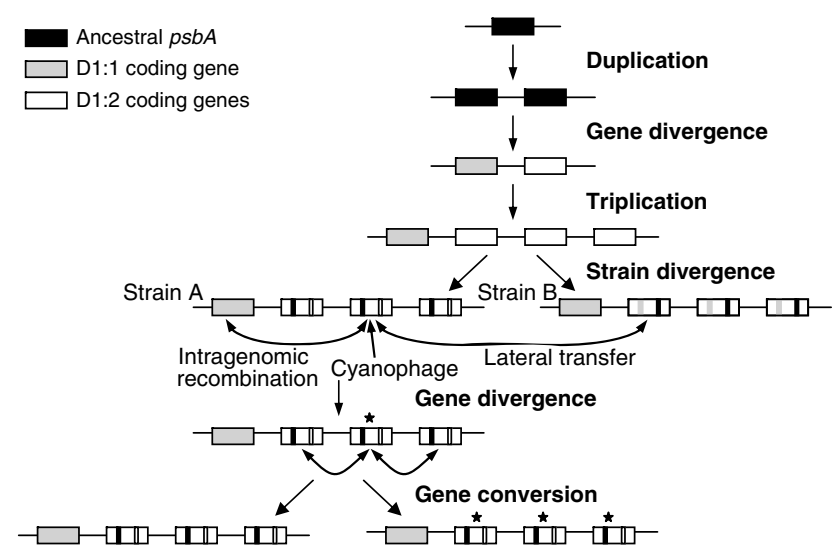

Figure 8 Model of evolution of marine Synechococcus psbA genes. After duplication of a $p s b A$ gene precursor (black box), leading to the emergence of the D1:1 (light grey box) and D1:2 (white box) isoform-coding genes, the triplication of the latter gene probably occurred in an ancestral cyanobacterium. Although there is a low degree of divergence between $p s b A$ sequences of marine Synechococcus strains, all psbA gene copies have followed a concerted evolution driven by intragenomic recombinations and lateral transfers from other strains and possibly viruses. D1:2-encoding genes also seem to have undergone an additional homogenization by gene conversion. Through this process, a mutation (indicated by a star) occurring in a D1:2-encoding gene, would be either eliminated or transmitted to other D1:2-encoding genes of the same strain (see online version for colour figure).

sp. WH7803, UV stress led to the induction of expression of SynWH7803_0790 encoding the D1:2 isoform, whereas the gene encoding D1:1, SynWH7803_0784, was repressed. These modifications were particularly striking in LL-acclimated cultures for which $p s b A$ gene encoding D1:1 isoform initially made up most of the $p s b A$ pool transcripts. In contrast, HL cultures already possess a larger initial pool of $p s b A$ transcripts encoding the D1:2 isoform, likely allowing better immediate resistance to UV stress. These observations are consistent with those of MacDonald et al. (2003) who reported that acclimation to higher PAR potentiated Synechococcus sp. PCC 7942 to tolerate a higher UVB level. Similarly, field studies have shown that phytoplankton sensitivity to surface UVB exposure was influenced by their previous light history (Bouchard et al., 2005).

Several mechanisms have been proposed to explain PSII photoinhibition by UV, all of them involving reactive oxygen species. It is thought that UV generates oxidative stress either by excessive reduction of the primary electron acceptor of PSII $\mathrm{Q}_{\mathrm{A}}$ (Vass et al., 1992) or by provoking charge recombination between PSII acceptor and donor sides (Keren et al., 1997). Reactive oxygen species have been suggested to be involved in the direct inactivation of PSII reaction centre through D1 protein cleavage (Vass et al., 1992), and also inhibits PSII repair by blocking the elongation step of protein translation, preventing D1 protein de novo synthesis (Nishiyama et al., 2001, 2006). Indeed, we have observed in the LL (and some of the ML) cultures exposed to UV the formation of cross-linked products of the large subunit of the RuBisCO (RbcL; data not shown), a phenomenon previously correlated with transient changes in cellular levels of reactive oxygen species (Wilson et al., 1995; Yosef et al., 2004). This indicates that these LL and ML cultures underwent a strong oxidative stress under UV exposure. Since no cross-linked products of the RuBisCO subunit were detected in any of the cultures exposed to HL, a difference in reactive oxygen species accumulation between the two types of treatments could partially explain the differential susceptibility of Synechococcus to UV and HL stresses.

LL and ML cells also exhibited different responses throughout HL exposure. When exposed to HL, the PSII quantum yield of LL cultures dropped sharply (Figure 2), while D1 protein content transiently doubled (Figure 3). Hence, most of these D1 proteins were not participating in functional PSII centres. These may be de novo synthesized products still not incorporated in the PSII cores, and/or D1 proteins that have not been cleared from photoinactivated PSII. In contrast to LL cultures, ML cultures rapidly acclimated to HL conditions with damaged D1 clearance coordinated with PSII photoinactivation. Indeed, although the PSII quantum yield of ML cultures decreased somewhat during the first hour of HL exposure, no fluctuations in D1 protein abundance was observed (Figures $2 \mathrm{~b}$ and $3 \mathrm{~d}$ ). In fact, PSII quantum yield rapidly stabilized at the initial value of HL cultures, indicating a nearly full acclimation to the new light conditions. The complementary acclimation was also observed in the reverse experiment, when the HL cultures were transferred to ML, as the D1 content did not vary during these experiments and the PSII quantum yield quickly increased and stabilized at a level close to that of ML cultures. In both cases, the change observed in PSII quantum yield may not reflect insufficient turnover of the D1 protein but rather a modification of the photosynthetic activity of the PSII complex. It is likely that the D1:1 isoform confers a higher PSII activity than D1:2 (Campbell et al., 1996), but the latter form provides a lower quantum yield but a higher PSII resistance to photoinhibition (Krupa et al., 1991; Clarke et al., 1993a,b; Campbell et al., 1995, 1998; Tichy et al., 2003), by increasing the probability of excitation dissipation in PSII centres (Sane et al., 2002). This hypothesis is consistent with the fact that HL-acclimated cells, which express mostly the D1:2 isoform genes (Figure 4), exhibit a lower PSII quantum yield. The switch between D1 isoforms, indicated by transcript (Figure 4), could thus be seen as a trade off between PSII activity and PSII photoprotection.

It is likely that the mechanism described here for Synechococcus sp. WH7803 occurs in most marine Synechococcus and constitutes a fundamental 
photophysiological trait of these ubiquitous organisms that inhabit diverse light environments. Indeed, examination of all marine Synechococcus genomes available to date shows a range for the $p s b A$ copy number, with all having a single D1:1 but several, up to five, D1:2-encoding genes per genome. The extremely low level of sequence divergence among the D1:2 coding genes and their independent clustering within all marine Synechococcus indicates a concerted evolution of these genes within a genome. This strongly suggests a homogenization of these sequences by gene conversion, defined as a non-reciprocal transfer of genetic information between highly homologous sequences (Santoyo and Romero, 2005). Through this process, paralogues within a species stay highly similar and yet continue to diverge among species. This mechanism is associated here with the occurrence of numerous translocations of orthologues adjacent to D1: 2-encoding genes (Figure 5), indicating recurrent recombination events between these genes (Hurles, 2004). Noteworthy, the two $p s b A$ genes responding most sharply to the exposure to UV and HL, SynWH7803_0790 and SynWH7803_0784, are located in the same genomic region (genomic region 3) in which more genomic rearrangements seem to have occurred when there is a D1:2 copy located downstream the D1:1 gene. This situation suggests that some strains could have carried a D1:2 gene copy in the genomic region 3 , which would have been secondarily lost during one of the recombination events. The evolution of the D1:2coding sequences thus appears to be the result of two counteracting processes: mutation and gene conversion. While mutation creates diversity between the D1:2 psbA copies, gene conversion tends to homogenize all copies within the genome in favour of the mutated or the original one and thus to decrease intragenomic divergence.

This concerted evolution of D1:2-encoding genes seems to be common to most cyanobacteria. Examination of freshwater cyanobacteria such as the two Anabaena or the two Synechococcus strains indeed shows that each strain possesses a set of nearly identical D1:2-encoding genes, as in marine Synechococcus (Figure 6). Furthermore, considering more distantly related strains, both isoforms cluster according to their genome. This observation clearly shows that, on a larger time scale, a certain degree of concerted evolution by recombination also occurred between both isoforms in freshwater cyanobacteria. In marine Synechococcus strains, the existence of a significant level of intragenomic recombination between D1:1- and D1:2-coding genes was confirmed by evolutionary network as well as recombination and statistical tests (Table 3). Recombination events have also been identified between marine Synechococcus strains, suggesting lateral transfers of $p s b A$ fragments between strains co-occurring in a same niche. Lastly, previous studies have shown that most Synechococcus cyanophage genomes contain a $p s b A$ gene closely related to the ones of their host and that genetic exchange of $p s b A$ fragments may have occurred from phage to host through direct environmental DNA uptake or through viral intermediates (Zeidner et al., 2005; Sullivan et al., 2006). As suggested by Sullivan et al. (2006), these lateral transfers could be one of the reasons explaining the incongruent phylogeny of Synechococcus psbA genes compared to the one obtained with concatenated ribosomal protein sequences (Six et al., 2007c) or other phylogenetic markers (Palenik, 2001; Rocap et al., 2002; Fuller et al., 2003; Lindell et al., 2005).

Such a mechanism of evolution, involving recombinations across all $p s b A$ genes, can also be related to the function and structure of the D1 protein. This protein indeed belongs to a core set of proteins that are extremely conserved due to protein-protein, protein-cofactor, and protein-substrate interactions that are critical to energy transduction (Shi et al., 2005). A striking example concerns the essential amino acid at position 130: although localized in a psbA segment affected by recombination between both isoform genes (Figure 7), the Gln and Glu residues are maintained in D1:1 and D1:2, respectively. Therefore, D1 proteins undergo a strong purifying selection and most amino acid changes are likely selected against. The coevolution of both D1 isoforms, while maintaining their respective functional specificity, would then allow maintaining the essential function of these proteins and their interactions with other protein members in the core photosynthetic machinery.

Several general trends in the evolutionary process of this protein family can be inferred from our study (Figure 8). The occurrence of both D1 isoforms in most cyanobacteria indicates that the common ancestor of these organisms probably possessed one D1:1- and two or three D1:2-encoding genes. Noticeable exceptions are the green oxyphotobacteria, Prochloron, Prochlorothrix and Prochlorococcus, which only carry one to three $p s b A$ gene copies encoding only the D1:1 isoform (Hess et al., 1995; Partensky and Garczarek, 2003). However, these organisms are atypical cyanobacteria in that they differ in their light harvesting system, which is an integral membrane $\mathrm{Chl} b$-binding antenna instead of the extrinsic phycobilisome found in most cyanobacteria (LaRoche et al., 1996; Garczarek et al., 2000). Considering the strong interactions among PSII apoproteins and antenna proteins, the acquisition of the green oxyphotobacteria-specific antenna most likely co-occurred with the loss of the D1:2-encoding genes. In contrast, all marine Synechococcus still possess D1:1- and D1:2-encoding genes. As in most cyanobacteria, both genes encoding D1 isoforms seem to be submitted to two distinct evolutionary processes, both of them leading to concerted evolution (Figure 8). While all $p s b A$ gene copies follow a concerted evolution through intragenomic recombinations and lateral 
transfers from other strains and possibly viruses, D1:2-encoding genes seem to undergo an additional homogenization through gene conversion, which would either eliminate or transmit mutation(s) to other D1:2-encoding genes of the same strain. In contrast, we hypothesize that the need to maintain the functional specificity of the D1:1 isoform prevents gene conversion between D1:1 and D1:2 genes. In any case, functional and structural constraints of D1 protein isoforms appear to be the driving force of the coevolution of $p s b A$ genes. Such numerous recombination events probably also affect the regulation of these genes at the transcriptional level in Synechococcus strains.

\section{Acknowledgements}

This work was supported by the Region Bretagne (program IMPALA), the French programs PROOF-UVECO and ANR PhycoSyn as well as the EU program SynChips (Marine Genomics Europe). We thank NSERC of Canada for operation and Canada Research Chairs for personnel funding (DAC) and the Canada Foundation for innovation for infrastructure (DAC).

\section{References}

Ahlgren NA, Rocap G. (2006). Culture isolation and culture-independent clone libraries reveal new marine Synechococcus ecotypes with distinctive light and N physiologies. Appl Envirol Microbiol 72: 7193-7204.

Allakhverdiev SI, Murata N. (2004). Environmental stress inhibits the synthesis de novo of proteins involved in the photodamage-repair cycle of Photosystem II in Synechocystis sp. PCC 6803. Biochim Biophys Acta 1657: 23-32.

Altschul S, Madden T, Schaffer A, Zhang J, Zhang Z, Miller W et al. (1997). Gapped BLAST and PSI-BLAST: a new generation of protein database search programs. Nucleic Acids Res 25: 3389-3402.

Aro EM, Suorsa M, Rokka A, Allahverdiyeva Y, Paakkarinen V, Saleem A et al. (2005). Dynamics of photosystem II: a proteomic approach to thylakoid protein complexes. J Exp Bot 56: 347-356.

Aro EM, Virgin I, Andersson B. (1993). Photoinhibition of photosystem 2-inactivation, protein damage and turnover. Biochim Biophys Acta 1143: 113-134.

Bouchard JE, Roy S, Ferreyra GA, Campbell DA, Curtosi A. (2005). Ultraviolet-B effects on photosystem II efficiency of natural phytoplankton communities from Antarctica. Polar Biol 28: 607-618.

Bruen TC, Philippe H, Bryant D. (2006). A simple and robust statistical test for detecting the presence of recombination. Genetics 172: 2665-2681.

Bustos SA, Schaefer MR, Golden SS. (1990). Different and rapid responses of four cyanobacterial psbA transcripts to changes in light intensity. J Bacteriol 172: 1998-2004.

Campbell D, Bruce D, Carpenter C, Gustafsson P, Oquist G. (1996). Two forms of the photosystem II D1 protein alter energy dissipation and state transitions in the cyanobacterium Synechococcus sp. PCC 7942. Photosynth Res 47: 131-144.
Campbell D, Clarke AK, Gustafsson P, Öquist G. (1999). Oxygen-dependent electron flow influences Photosystem II function and $p s b A$ gene expression in the cyanobacterium Synechococcus sp. PCC 7942. Physiol Plant 105: 746-755.

Campbell D, Eriksson MJ, Oquist G, Gustafsson P, Clarke AK. (1998). The cyanobacterium Synechococcus resists UV-B by exchanging photosystem II reaction-center D1 proteins. Proc Natl Acad Sci USA 95: $364-369$.

Campbell D, Zhou GQ, Gustafsson P, Oquist G, Clarke AK. (1995). Electron transport regulates exchange of two forms of photosystem II D1 protein in the cyanobacterium Synechococcus. EMBO J 14: 5457-5466.

Clarke AK, Campbell D, Gustafsson P, Öquist G. (1995). Dynamic responses of the photosystem II and phycobilisomes to changing light in the cyanobacterium Synechococcus sp. PCC 7942. Planta 197: $553-562$

Clarke AK, Hurry VM, Gustafsson P, Oquist G. (1993a). Two functionally distinct forms of the photosystem II reaction-center protein D1 in the cyanobacterium Synechococcus sp. PCC 7942. Proc Natl Acad Sci USA 90: 11985-11989.

Clarke AK, Soitamo A, Gustafsson P, Oquist G. (1993b). Rapid interchange between two distinct forms of cyanobacterial photosystem II reaction-center protein D1 in response to photoinhibition. Proc Natl Acad Sci USA 90: 9973-9977.

Enright AJ, van Dongen S, Ouzonis CA. (2002). An efficient algorithm for large-scale detection of protein families. Nucleic Acids Res 30: 1575-1584.

Fuller NJ, Marie D, Partensky F, Vaulot D, Post AF, Scanlan DJ. (2003). Clade-specific $16 \mathrm{~S}$ ribosomal DNA oligonucleotides reveal the predominance of a single marine Synechococcus clade throughout a stratified water column in the Red Sea. Appl Envirol Microbiol 69: $2430-2443$

Garcia-Fernandez JM, Hess WR, Houmard J, Partensky F. (1998). Expression of the $p s b A$ gene in the marine oxyphotobacteria Prochlorococcus spp. Arch Biochem Biophys 359: 17-23.

Garczarek L, Hess WR, Holtzendorff J, van der Staay GW, Partensky F. (2000). Multiplication of antenna genes as a major adaptation to low light in a marine prokaryote. Proc Natl Acad Sci USA 97: 4098-4101.

Giorgi LB, Nixon PJ, Merry SA, Joseph DM, Durrant JR, de Las Rivas J et al. (1996a). Comparison of primary charge separation in the photosystem II reaction center complex isolated from wild-type and D1-130 mutants of the cyanobacterium Synechocystis PCC 6803. J Biol Chem 271: 2093-2101.

Giorgi LB, Nixon PJ, Merry SA, Joseph DM, Durrant JR, De Las Rivas J et al. (1996b). Comparison of primary charge separation in the photosystem II reaction center complex isolated from wild-type and D1-130 mutants of the cyanobacterium Synechocystis PCC 6803. J Biol Chem 271: 2093-2101.

Guindon S, Gascuel O. (2003). A simple, fast, and accurate algorithm to estimate large phylogenies by maximum likelihood. Syst Biol 52: 696-704.

Hall TA. (1999). BioEdit: a user-friendly biological sequence alignment editor and analysis program for Windows 95/98/NT. Nucleic Acids Symp Ser 41: 95-98.

Hess WR, Weihe A, Loiseaux-de Goër S, Partensky F, Vaulot D. (1995). Characterization of the single 
psbA gene of Prochlorococcus marinus CCMP 1375 (Prochlorophyta). Plant Mol Biol 27: 1189-1196.

Hurles M. (2004). Gene duplication: the genomic trade in spare parts. PLoS Biol 2: E206.

Huson DH, Bryant D. (2006). Application of phylogenetic networks in evolutionary studies. Mol Biol Evol 23: 254-267.

Kana TM, Glibert PM. (1987). Effect of irradiances up to $2000 \mu \mathrm{E} \mathrm{m}^{-2} \mathrm{~s}^{-1}$ on marine Synechococcus WH7803II. Photosynthetic responses mechanisms.. Deep-Sea Res 34: 497-516.

Keren N, Berg A, van Kan PJ, Levanon H, Ohad II. (1997). Mechanism of photosystem II photoinactivation and D1 protein degradation at low light: the role of back electron flow. Proc Natl Acad Sci USA 94: 1579-1584.

Kos PB, Deak Z, Cheregi O, Vass I. (2008). Differential regulation of $p s b A$ and $p s b D$ gene expression, and the role of the different D1 protein copies in the cyanobacterium Thermosynechococcus elongatus BP-1. Biochim Biophys Acta 1777: 74-83.

Kosakovsky Pond SL, Posada D, Gravenor MB, Woelk CH, Frost SDW. (2006). Automated phylogenetic detection of recombination using a genetic algorithm. Mol Biol Evol 23: 1891-1901.

Krupa Z, Oquist G, Gustafsson P. (1991). Photoinhibition of photosynthesis and growth responses at different light levels in $p s b A$ gene mutants of the cyanobacterium Synechococcus. Physiol Plant 82: 1-8.

Kumar S, Tamura K, Nei M. (2004). MEGA3: integrated software for molecular evolutionary genetics analysis and sequence alignment. Brief Bioinform 5: 150-163.

LaRoche J, van der Staay GW, Partensky F, Ducret A, Aebersold R, Li R et al. (1996). Independent evolution of the prochlorophyte and green plant chlorophyll a/b light-harvesting proteins. Proc Natl Acad Sci USA 93: 15244-15248.

Lindell D, Penno S, Al-Qutob M, David E, Rivlin T et al. (2005). Expression of the nitrogen stress response gene ntcA reveals nitrogen-sufficient Synechococcus populations in the oligotrophic northern Red Sea. Limnol Oceanogr 50: 1932-1944.

MacDonald TM, Dubois L, Smith LC, Campbell DA. (2003). Sensitivity of cyanobacterial antenna, reaction center and CO2 assimilation transcripts and proteins to moderate UVB: light acclimation potentiates resistance to UVB. Photochem Photobiol 77: 405-412.

Marie D, Brussaard C, Partensky F, Vaulot D. (1999). Flow cytometric analysis of phytoplankton, bacteria and viruses. In: Sons JW (ed). Current Protocols in Cytometry. International Society for Analytical Cytology. pp 11.11.11-11.11.15.

Marie D, Simon N, Guillou L, Partensky F, Vaulot D. (2000). DNA, RNA analysis of phytoplankton by flow cytometry. In: Current Protocols in Cytometry. John Wiley \& Sons, pp 11.12.11-11.12.14.

Mary I, Vaulot D. (2003). Two-component systems in Prochlorococcus MED4: Genomic analysis and differential expression under stress. FEMS Microbiol Lett 226: 135-144.

Mate Z, Sass L, Szekeres M, Vass I, Nagy F. (1998). UV-Binduced differential transcription of $p s b A$ genes encoding the D1 protein of photosystem II in the cyanobacterium Synechocystis 6803. J Biol Chem 273: 17439-17444.

Moore LR, Goericke R, Chisholm SW. (1995). Comparative physiology of Synechococcus and Prochlorococcus: influence of light and temperature on growth, pigments, fluorescence and absorptive properties. Mar Ecol Prog Ser 116: 259-275.

Nishiyama Y, Allakhverdiev SI, Murata N. (2006). A new paradigm for the action of reactive oxygen species in the photoinhibition of photosystem II. Biochim Biophys Acta 1757: 742-749.

Nishiyama Y, Yamamoto H, Allakhverdiev SI, Inaba M, Yokota A, Murata N. (2001). Oxidative stress inhibits the repair of photodamage to the photosynthetic machinery. EMBO J 20: 5587-5594.

Olson RJ, Zettler ER, Armbrust EV, Chisholm SW. (1990). Pigment, size and distribution of Synechococcus in the North Atlantic and Pacific oceans. Limnol Oceanogr 35: 45-58.

Palenik B. (2001). Chromatic adaptation in marine Synechococcus strains. Appl Envirol Microbiol 67: 991-994.

Partensky F, Blanchot J, Vaulot D. (1999). Differential distribution and ecology of Prochlorococcus and Synechococcus in oceanic waters: a review. In: Charpy L, Larkum AWD (eds). Marine Cyanobacteria. Musée Océanographique: Monaco. pp 457-475.

Partensky F, Garczarek L. (2003). The photosynthetic apparatus of chlorophyll b- and d-containing Oxychlorobacteria. In: Larkum AWD (ed). Photosynthesis in Algae. Kluwer Academic Publishers: Dordrecht. pp 29-62.

Rippka R, Coursin T, Hess W, Lichtlé C, Scanlan DJ, Palinska KA et al. (2000). Prochlorococcus marinus Chisholm et al. 1992 subsp. pastoris subsp. nov. strain PCC 9511, the first axenic chlorophyll a2/b2containing cyanobacterium (Oxyphotobacteria). Int J Syst Evol Microbiol 50: 1833-1847.

Rocap G, Distel DL, Waterbury JB, Chisholm SW. (2002). Resolution of Prochlorococcus and Synechococcus ecotypes by using 16S-23S ribosomal DNA internal transcribed spacer sequences. Appl Envirol Microbiol 68: 1180-1191.

Sander J, Nowaczyk M, Rogner M. (2007). Role of the psbA gene family of PSII from the thermophilic cyanobacterium. Thermosynechococcus elongatus. 14th Photosynthesis Congress, Glasgow, p PS4.14.

Sane PV, Ivanov AG, Sveshnikov D, Huner NPA, Oquist G. (2002). A transient exchange of the photosystem II reaction center protein D1:1 with D1:2 during low temperature stress of Synechococcus sp. PCC 7942 in the light lowers the redox potential of Q(B). $J$ Biol Chem 277: 32739-32745.

Santoyo G, Romero D. (2005). Gene conversion and concerted evolution in bacterial genomes. FEMS Microbiol Rev 29: 169-183.

Schaefer MR, Golden SS. (1989). Differential expression of members of a cyanobacterial psbA gene family in response to light. J Bacteriol 171: 3973-3981.

Shi T, Bibby TS, Jiang L, Irwin AJ, Falkowski PG. (2005). Protein interactions limit the rate of evolution of photosynthetic genes in cyanobacteria. Mol Biol Evol 22: 2179-2189.

Sicora CI, Appleton SE, Brown CM, Chung J, Chandler J, Cockshutt AM et al. (2006). Cyanobacterial psbA families in Anabaena and Synechocystis encode trace, constitutive and UVB-induced D1 isoforms. Biochim Biophys Acta 1757: 47-56.

Sicora CI, Brown CM, Vass I, Cheregi O, Campbell DA. (2008). The $p s b A$ gene family responds differentially 
to light and UVB stress in Gloeobacter violaceus PCC 7421, a deeply divergent cyanobacterium. $B B A$ 777: 130-139.

Sippola K, Kanervo E, Murata N, Aro EM. (1998). A genetically engineered increase in fatty acid unsaturation in Synechococcus sp. PCC 7942 allows exchange of D1 protein forms and sustenance of photosystem II activity at low temperature. Eur $J$ Biochem 251: 641-648.

Six C, Finkel ZV, Irwin AJ, Campbell DA. (2007a). Light variability illuminates Niche-Partitioning among Marine Picocyanobacteria. PLoS ONE 2: e1341.

Six C, Joubin L, Partensky F, Holtzendorff J, Garczarek L. (2007b). UV-induced phycobilisome dismantling in the marine picocyanobacterium Synechococcus sp. WH 8102. Photosynth Res 92: 75-86.

Six C, Thomas JC, Garczarek L, Ostrowski M, Dufresne A, Blot $\mathrm{N}$ et al. (2007c). Diversity and evolution of phycobilisomes in marine Synechococcus spp.: a comparative genomics study. Genome Biol 8: R259.

Six C, Thomas JC, Brahamsha B, Lemoine Y, Partensky F. (2004). Photophysiology of the marine cyanobacterium Synechococcus sp. WH8102, a new model organism. Aquat Microb Ecol 35: 17-29.

Sullivan MB, Lindell D, Lee JA, Thompson LR, Bielawski JP, Chisholm SW. (2006). Prevalence and evolution of core photosystem II genes in marine cyanobacterial viruses and their hosts. PLoS Biol 4: e234.

Thompson JD, Higgins DG, Gibson TJ. (1994). CLUSTAL W: improving the sensitivity of progressive multiple sequence alignment through sequence weighting, position-specific gap penalties and weight matrix choice. Nucleic Acids Res 22: 4673-4680.

Tichy M, Lupinkova L, Sicora C, Vass I, Kuvikova S, Prasil O et al. (2003). Synechocystis 6803 mutants expressing distinct forms of the Photosystem II D1 protein from Synechococcus 7942: relationship between the psbA coding region and sensitivity to visible and UV-B radiation. Biochim Biophys Acta 1605: 55-66.

Vass I, Styring S, Hundal T, Koivuniemi A, Aro E, Andersson B. (1992). Reversible and irreversible intermediates during photoinhibition of photosystem II: stable reduced QA species promote chlorophyll triplet formation. Proc Natl Acad Sci USA $\mathbf{8 9}$ 1408-1412.

Vass I, Kirilovsky D, Perewoska I, Mate Z, Nagy F, Etienne AL. (2000). UV-B radiation induced exchange of the D1 reaction centre subunits produced from the psbA2 and psbA3 genes in the cyanobacterium Synechocystis sp PCC 6803. Eur J Biochem 267: 2640-2648.

Vrba JM, Curtis SE. (1990). Characterization of a fourmember $p s b A$ gene family from the cyanobacterium Anabaena PCC 7120. Plant Mol Biol 14: 81-92.

Waterbury JB, Watson SW, Valois FW, Franks DG. (1986). Biological and ecological characterization of the marine unicellular cyanobacterium Synechococcus. Can Bull Fish Aquat Sci 214: 71-120.

Wilson MI, Ghosh S, Gerhardt KE, Holland N, Babu TS, Edelman $\mathrm{M}$ et al. (1995). In vivo photomodification of ribulose-1,5-bisphosphate carboxylase/oxygenase holoenzyme by Ultraviolet-B radiation (formation of a 66-Kilodalton Variant of the Large Subunit). Plant Physiol 109: 221-229.

Yosef I, Irihimovitch V, Knopf JA, Cohen I, Orr-Dahan I, Nahum E et al. (2004). RNA binding activity of the ribulose-1,5-bisphosphate carboxylase/oxygenase large subunit from Chlamydomonas reinhardtii. J Biol Chem 279: 10148-10156.

Zeidner G, Bielawski JP, Shmoish M, Scanlan DJ, Sabehi G, Beja O. (2005). Potential photosynthesis gene recombination between Prochlorococcus and Synechococcus via viral intermediates. Environ Microbiol 7: 1505-1513.

Supplementary Information accompanies the paper on The ISME Journal website (http://www.nature.com/ismej) 